\title{
THE INFLUENCE OF BLAŽ KOCEN (BLASIUS KOZENN) AND HIS GEOGRAPHICAL ATLAS ON THE DEVELOPMENT OF CROATIAN SCHOOL CARTOGRAPHY
}

Izvirni znanstveni članek

COBISS 1.01

DOI: 10.4312/dela.56.193-218

\section{Abstract}

In this paper, we analyze the importance of Kocen's atlases for the development of Croatian school cartography. Comparing German and Croatian editions in the period between 1887 and 1943, we follow the progress in map printing, cartographic techniques, language redactions of toponymy as well as the inclusion of thematic maps and the influence of political discourse (German centralism vs. Slavic nationalisms) on the geographical scope and content of maps used in the educational process.

Keywords: Croatian school cartography, geography teaching, national identity, Blaž Kocen (Blasius Kozenn) 


\section{VPLIV BLAŽA KOCENA (BLASIUSA KOZENNA) IN NJEGOVEGA GEOGRAFSKEGA ATLASA NA RAZVOJ HRVAŠKE ŠOLSKE KARTOGRAFIJE}

\section{Izvleček}

V prispevku analiziramo pomen Kocenovih atlasov za razvoj hrvaške šolske kartografije. S primerjavo nemških in hrvaških izdaj v obdobju med letoma 1887 in 1943 spremljamo razvoj na področju tiskanja zemljevidov, kartografskih tehnik, jezikovnih redakcij toponimije in vključevanja tematskih kart ter vpliv političnega diskurza (nemški centralizem proti slovanskim nacionalizmom) na geografski obseg in vsebino zemljevidov, ki so jih uporabljali v izobraževalnem procesu.

Ključne besede: hrvaška šolska kartografija, poučevanje geografije, nacionalna identiteta, Blaž Kocen (Blasius Kozenn)

\section{INTRODUCTION}

Blaž Kocen, also known as Blasius Kozenn (1821, Hotunje near Ponikva - 1871, Vienna) is one of the most prominent Slovene geographers and cartographers who worked at the turbulent times marked by the modernization of education system in the countries of the Austrian Empire, i.e. Austro-Hungarian Monarchy (since 1867). Initially trained as a priest and then educated in mathematics, physic, and natural sciences, he distinguished himself in teaching of geography, advocating the use of more advanced teaching tools. In order to improve teaching process Kocen wrote several geography textbooks and compiled numerous wall and table maps. No doubt, Kocen's crowning accomplishment was his school geographical atlas. After its first edition in 1861, Kocen's atlas continued to improve and adapt to new historical circumstances even after author's untimely death, leaving a lasting mark in the school cartography of all Central European countries. Based on Kocen's template, adapted editions soon followed published in Croatian, Czech, Hungarian and Polish language, making it the most important geographical school atlas within Austro-Hungary. Since then, atlas that saw at least 278 editions on six languages, still represents a synonym for a high quality school atlas.

When the first edition of Kocen's Geographischer Schul-Atlas für die Gymnasien, Real- und Handels-Schulen appeared in 1861 as the first school geographical atlas prepared for the use in countries of the Austrian Empire, it was a scientific and didactic sensation. For the first time, teachers of geography received a manual in the form of an atlas that was harmonized with the curriculum of the countries of the Empire. This was also true for Croatia, where the Croatian language became the official language 
in that same year, and the curriculum and all textbooks had to be adapted to this new situation. Until 1861, the teaching of geography as well as the development of Croatian cartography in the local language was prevented by the use of German as the official language. In fact, except for the short period of 1847-1853, teaching, as well as all manuals, including maps, were exclusively in German. Reconvened in 1861, the Croatian Parliament reintroduced the use of Croatian as the official language in Croatia and Slavonia (however, not in the territories of the Military Frontier, Dalmatia and Istria!), and brought a series of modernization reforms that had a strong impact on education, science and culture. It adopted laws on elementary and secondary schools, as well as on teacher training colleges. The matters discussed were further reconstruction of the University, the establishment of the Yugoslav Academy of Arts and Sciences, and the organizational structure of the National Museum, founded in 1846. Such intensive legislative work of the Parliament laid the foundations for the modernization of local administration and judiciary, as well as for the educational reorganization of Croatia. Particularly important was a decision on the independence and territorial integrity of the Triune Kingdom, that is to say, the entitlement of Croatia to the Croatian Military Frontier and Dalmatia, as well as Croatian independence in matters of internal affairs, justice, religion, and education that was subsequently confirmed by the ruler himself (Stančić, 2002, p. 183).

The political changes that took place in 1860/1861 had powerful reverberations in the educational and scientific system, which also boosted development of national cartography. The development of geography had a particularly strong influence, in both the school system and the field of scientific research. The advances in the geography as a scientific discipline were directly reflected in the content and quality of local cartographic production. In 1866, the Yugoslav Academy of Arts and Sciences was founded while in 1874, a modern university was founded in Zagreb (Gross, Szabo, 1992, p. 415). These institutions were the main instigators of modernization processes, creating preconditions for the development of modern civil society in the fields of science and education.

The significant changes initiated in the school system were to additionally encourage the development of so-called national sciences. School books, which until 1862 were exclusively printed by the educational publisher K.u.k. Schulbuchverlag in Vienna, after 1862 started being printed in Zagreb (Cuvaj, 1910, V, p. 139; Modrić Blivajz, 2007, p. 782). This especially boosted the domestic production of textbooks on geography. In the 1860s, Croatia saw the emergence of a pleiad of distinguished geographers. They had studied at prestigious German universities, but published their books in Croatian. As early as 1861, Václav Záboj Mařik, published his book Kratak opis Carevine Austrijanske [A Brief Description of the Austrian Empire]. Soon other books followed; in 1865 Mařik wrote Zemljopis Trojedne Kraljevine [The Geography of the Triune Kingdom], Petar Zoričić prepared Zemljopis za niže realke i niže gimnazije [Geography for Lower Secondary Schools and Lower Grammar Schools], while in 1867 the Slovene pedagogue Franjo Bradaška published Sravnjivajući zemljopis za 
više razrede srědnjih učionah [Geography for Higher Grades of Secondary Schools]. In addition to Mařik and Bradaška, another geographer who started his scientific career around the same time was Petar Matković, the first university professor of geography in Croatia. As founder of the Department of Geography at the Faculty of Philosophy in Zagreb and its first professor, he was considered the founder of geographical science in Croatia. Having started his scientific work in 1866, Matković published a book entitled Statistika Austrijske Carevine [The Statistics of the Austrian Empire]. In 1874, it was followed by a book titled Geografsko-statistički nacrt Austro-Ugarske Monarhije [A Geographical and Statistical Review of the Austro-Hungarian Monarchy], which underwent numerous editions (Altić, 2019, pp. 104-105). Of great significance for the development of geography and the geographic knowledge of the Croatian lands was also Vinko Sabljar's book Miestopisni riečnik kraljevinah Dalmacije, Hervatske $i$ Slavonije [The Toponymic Dictionary of the Kingdoms of Dalmatia, Croatia and Slavonia], published in Zagreb in 1866. On the other hand, Bogoslav Šulek had a particular influence on the development of professional geographic terminology. He published the Hrvatsko-njemačko-talijanski rječnik znanstvenog nazivlja [The Croatian-German-Italian Dictionary of Scientific Terminology] in Zagreb in 1874. Toponymy recording in the native language, the development of professional geographical terminology, and the progress in the geographic knowledge of the Croatian lands in general were also reflected in the advances in national cartographic efforts, which increasingly relied on recent achievements of local geographers as well. The appearance of the abovementioned textbooks played an important role in the midst of the Croatian national movement and the struggle for its own cultural identity within the Austro-Hungarian Monarchy. Geography and cartography were recognized as an important expression of national identity, especially in their educational dimension.

\section{USE OF GERMAN EDITIONS OF KOCEN'S ATLAS IN CROATIAN SCHOOLS}

The development of production of school textbooks in the Croatian language, which especially took place in the 1870s and 1880s, highlighted the problem of the lack of school maps in the Croatian language. A rather clumsy map of the Triune Kingdom made in 1861 by Franjo Kružić as the first school map of Croatia in the native language $^{1}$, or a bilingual (Croatian-German) map of Croatia and Slavonia by Michael Katzenschläger (numerous editions from 1855 onwards) ${ }^{2}$, which left out many Croatian countries, caused great difficulties for teachers (Cuvaj, 1910, IV, p. 119). It is interesting that cartography in public schools was then taught not only through the teaching of geography but also through the teaching of drawing, where the skill of the so-called surveying drawing was taught. ${ }^{3}$ In the absence of school atlases in the Croatian language, the use of Kocen's geographical atlas was allowed in secondary 
schools and high schools since 1861. Although published in German and modeled on German models of school atlases, Kocen's editing and gradual supplementation of each new edition managed to move the atlas somewhat away from traditional Germanocentric school atlases and create an original content adapted to a multicultural monarchy such as Austro-Hungary. In the early editions (until the creation of AustroHungary), the Croatian lands were shown on several maps: Dalmatia and the Military Frontier were shown on a map of the Austrian Empire $(1: 5,000,000)$, Croatia and Slavonia were included in the map of Hungary $(1: 2,000,000)$ which was later replaced by a map of the Carpathian countries as well as on a map of the South Slavic country inhabited by Croats and Serbs (1:2,000,000), which in 1862 was replaced by a map of European Turkey, Dalmatia, and the Military Frontier (1:4,000,000) (Dörflinger, Hühnel, 1995, II, pp. 519-521). Germanocentrism in Kocen's early editions was still very pronounced. The geographical focus on the German lands is obvious (in the 1865 edition there were no less than four maps of Germany), and the absence of thematic maps especially those on linguistic and ethnographic issues speaking in favor of strongly expressed centralism of the then European monarchies. This is a reflection of the use of German templates such as school atlases by Emil von Sydow, Adolf Stieler, Joseph Marx von Lichenstern, Karl Christian Ludwig Adami, and Heinrich Kiepert (Kocen himself cites them as the source in the introduction to his first edition).

Nevertheless, Kocen made some important steps forward. In addition to maps of political entities, he included in his atlas maps of individual natural geographical units (Central Europe, the Carpathian region, the Alpine countries, the Mediterranean), which was extremely innovative at the time (Bratec Mrvar, 2011, p. 94). He also drew the Slovene language border in the map of the Alpine countries, ${ }^{4}$ and added a comparative index of German and Slovenian geographical names for Slovenian settlements, which was omitted in editions published after Kocen's death (Bratec Mrvar, 2011, p. 40). After 1868 , the atlas was supplemented with new maps that did not focus on Germany but on the Austro-Hungarian Monarchy and its countries, so several maps of individual countries of the Austrian and Hungarian crowns appeared such as Bohemia and Moravia, Galicia, Carniola, Istria and Goritz, etc. After Kocen's retirement in 1870, his successors Konrad Jarc, Friedrich Umlauft (since 1877), Vincenz von Haardt (since 1880), and Wilhelm Schmidt (since 1896) continued completing and adapting the atlas to new political circumstances within the Monarchy. From 1875, the first thematic maps began to appear in the atlas, which at least somewhat moved away from the strictly physical geographical aspect of space, and touched on some issues of social and economic geography. ${ }^{5}$ Nevertheless, despite the obvious progress, the Croatian countries in the atlas are still shown exclusively within larger geographical units (Croatia and Slavonia as part of the map of the Hungarian crown countries and Dalmatia together with Bosnia and Military Border, as well as, from 1877, together with Istria, Crain, and Goritz (and after 1880 again with Bosnia). This way of presenting the Croatian lands was in contradiction with the school curriculum of geography and history, which insisted on the unity 
of the Triune Kingdom (Croatia, Slavonia, Dalmatia). Also, a special problem was the geographical nomenclature that was Germanized or Italianized (in Istria and Dalmatia).

\section{CROATIAN EDITIONS OF KOCEN'S ATLAS AND THEIR DISTINCTIVE FEATURES}

In order to improve the teaching of geography and history, and harmonize curricula with teaching aids, Augustin Dobrilović, professor of geography and history and principal of the gymnasium in Kotor, decided in 1887 to compile a set of Croatian textbooks and atlases for Croatian schools. ${ }^{6}$ After he had published Zemljopis za niže razrede srednjih škola [Geography for the Lower Grades of Secondary Schools] (Zadar, 1887; Zagreb, 1892), he prepared two Croatian school atlases in the same year. First he translated and adapted Putzgers' historical atlas (F. W. Putzgers Historischer SchulAtlas) into Croatian ${ }^{7}$, and then, in collaboration with Petar Matković, ${ }^{8}$ the Croatian edition of Kocen's geographical atlas for secondary schools, which was published in Zagreb in 1887. More precisely, two editions of the abovementioned geographical atlas were published that year. First, an atlas with a set of 12 maps of Austro-Hungary was published as a separate volume in Vienna ${ }^{9}$, and then republished in Zagreb as a complete edition of the atlas with 37 maps covering the whole world, including previously published maps of Austro-Hungary ${ }^{10}$. All maps of Croatian editions were made as more or less literal translations of German editions. It is interesting that both Croatian editions of the geographical atlas from 1887 omit thematic maps that were already present in the German edition from 1887: a map of the Austro-Hungarian railway network and an ethnographic and linguistic map of the Monarchy.

\subsection{Geographical scope, content, and source maps}

The first Croatian edition of Kocen's atlas brings 12 maps relating to Austro-Hungary and its components, of which only two refer exclusively to Croatian lands. Maps referring to the entire Austro-Hungarian Monarchy (physical with a longitudinal section of the relief and a political-administrative map) were taken from a recently published German or Czech edition. Physical maps, Alpine countries (Upper and Lower Austria, Salzburg, Styria, Carinthia, Tyrol, Voralberg, Carniola, and Primorje), Carpathian countries (Hungary, Galicia, Bukovina), and Sudetenland (Czech Republic, Moravia, Silesia) that appeared in the German edition, in Croatian edition are supplemented with a political map for each of the above areas, which were adopted from the Czech edition. A particularly important intervention was the inclusion of a map Austrian Karst Regions and Occupied Lands (Bosnia and Herzegovina, Novi Pazar) at a scale of 1:2,000,000 through two maps, physical and political. It was a revision of a political map Dalmatia and the Occupied Territories that appeared in the 1880 German edition with the exactly 
same geographical coverage and content. For the Croatian countries, which are predominantly located on karst terrains, this map certainly had great significance. However, the inclusion of this map had a much greater political significance, and reflects the geopolitical changes that occurred after the Berlin Congress of 1878 and the Austrian occupation of Bosnia and Sanjak. The Austrian presence in Bosnia as well as the growing political pressures from Budapest encouraged the growth of Croatian nationalism and the increasingly common perception of Bosnia as a predominantly Croatian country. ${ }^{11}$ The inclusion of this map was a politically inconspicuous way to find all Croatian countries on one map, those under the Austrian (Istria, Dalmatia) and Hungarian crowns (Croatia and Slavonia), as well as Bosnia and Herzegovina. Due to the Austrian suppression of the South Slavic question, those countries rarely found places on the same map. Nonetheless, this map also maintained a specific Austrian discourse, which appropriated Croatia and Slavonia as Austrian (karst) countries.

Certainly the most important novelty of Dobrilovićs edition was the inclusion of two maps of Croatia and Slavonia at a scale of 1:1,500,000 (political and physical) (Figure 1). These were the first single geographical maps of Croatia and Slavonia in a school atlas. Interestingly, in 1876, a physical map of Croatia, Slavonia and Dalmatia at a scale of 1:2,500,000 appeared in Czech and German editions ${ }^{12}$. However, the Croatian edition of the physical and administrative maps of Croatia and Slavonia only partially relied on existing maps from Kocen's atlas. Given the much larger scale that required significant refinement of the geographical content, it is clear that other templates were used in the preparation of Croatian maps. Considering the geographical content, geographical nomenclature and the way the relief is presented, some of the recent editions of Katzenschläger's map of Croatia and Slavonia at a scale of 1:500,000, which was used in schools, stand out as the most probable template. ${ }^{13}$ Dobrilovićs presentation of relief by hatching and detailed administrative-territorial division largely coincides with Katzenschläger's map. Dobrilović and Matković played a particularly important role in adapting geographical nomenclature to the Croatian language, which was otherwise the weakest link on earlier maps of Croatian countries. This is especially reflected in the Croatian terminology for mountains (oronyms), islands (nesonyms), and certain mareonyms, which now were significantly improved. As a supplement for oronyms, mareonyms, and hypsometric data, they used a 1878 physical map of Croatia and Slavonia prepared by Karl Herdliczka and printed by Friedrich Köke, a close associate of Hölzel (Altić, 2019, p. 114).${ }^{14}$ Thus, to designate Podvelebitski kanal, which until then had been commonly called the Morlački kanal [Morlach's Channel] (according to the Italian name Morlacco for the Vlachs) he introduced the Croatian name Planinski kanal [Mountain Channel] under the influence of Herdliczka, Dobrilović, and Matković. Echoes of the geographical nomenclature of Herdliczka's map can be clearly seen in Dobrilovićs edition of the map of the Austrian karst regions as well, where a number of new Croatian mareonyms (for sea passages and channels) and nesonyms were adopted, which until then were listed exclusively in Italianized form. 

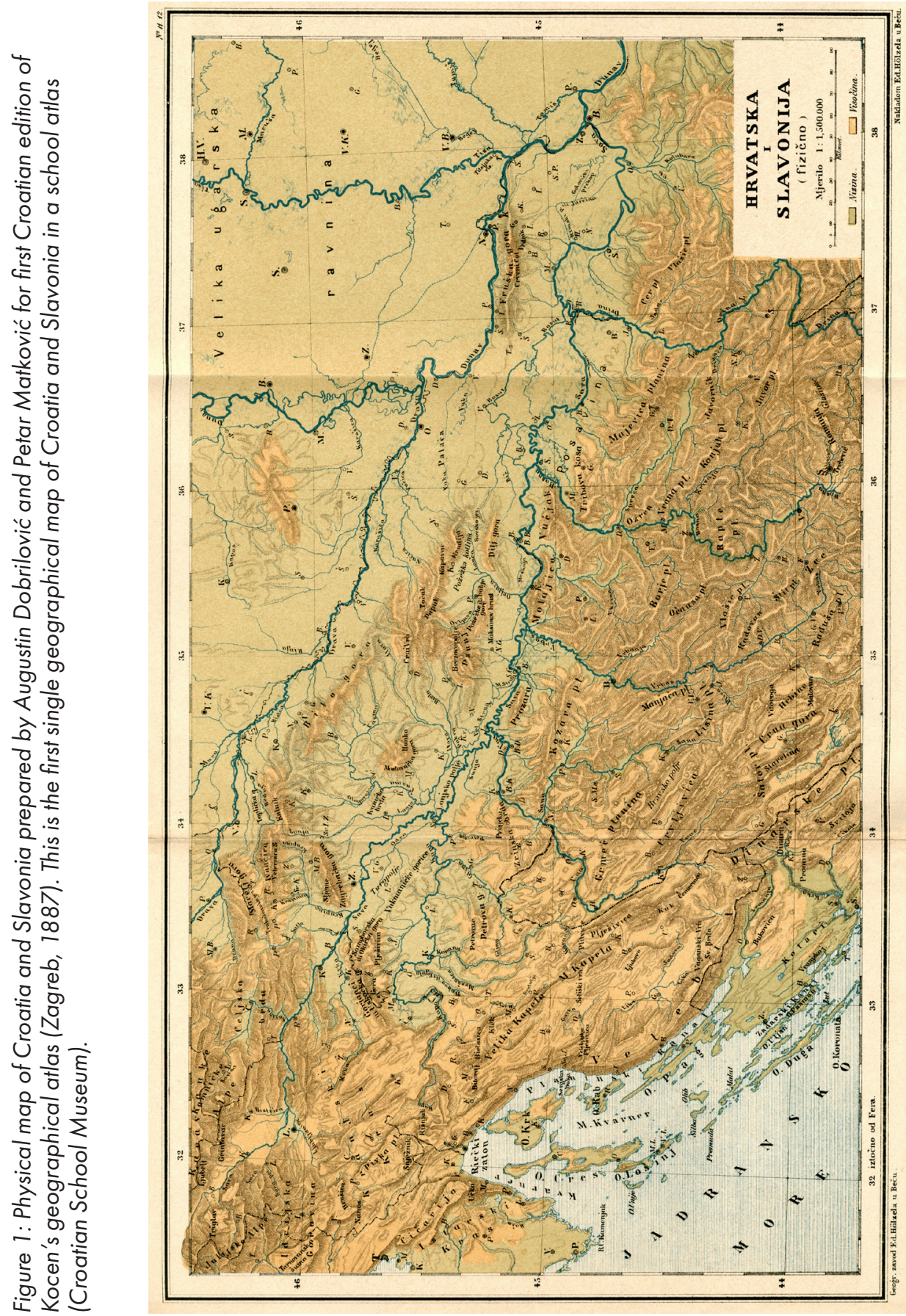


\subsection{Map production and geographic elements of maps}

Publisher of the Croatian editions was the Lavoslav Hartman Bookstore. Yet, the maps prepared by Croatian editors were technically finalized and printed in Vienna by Eduard Hölzel. In this sense, there is no difference in the technique and quality of printing between the identical Zagreb and Viennese editions. Both were executed by the lithographer Friedrich Köke (1823-1882), the head of the Geographical Department of the Hölzel Institute. Croatian editions were printed in multicolored lithography and mostly published in hardcover. The technique of multicolor lithography was improved in later editions, which was especially reflected in the more detailed elaboration of the hypsometric scale and in the stronger contrast of colors, which improved the legibility of maps.

Progress in the quality and manner of presentation of certain geographical elements on the maps of Croatian editions mainly coincides with the progress in German editions (sometimes with a time lag). All maps in the early Croatian editions were constructed according to Ferro prime meridian. From the early 20th century, Croatian editions started to refer to Greenwich (the same as German editions). ${ }^{15} \mathrm{Al}$ though the metric system was introduced as the official unit of measurement in Austria-Hungary from 1871, the scale of maps was expressed by a double scale in meters and geographical miles.

Due to excessive generalization and the inadequacy of the hypsometric scale, the presentation of relief was the weakest element of the maps (this also applies to German editions). The relief is shown by hatching on both physical and political maps. On physical maps, the presentation of the relief was supplemented with a hypsometric scale, which in the first Croatian editions was not adjusted to the altitude range of Croatian lands, so that the whole of Croatia and Slavonia falls into only two categories: lowlands and highlands. In the editions from 1900 onwards, the hypsometric scale was better defined (0-200 m, 200-500 m, 500-1000 m), so the presentation of the terrain was more credible, and was supplemented with height points. Another significant step forward in the quality of relief presentation was made when Milan Šnoa took over the editing of the atlas. He introduces the hypsometric scale with an equidistance of 100 meters, supplemented with numerous height points.

Administrative and political maps of Croatia and Slavonia are accompanied by more abundant socio-geographical elements like numerous settlements, traffic network, and borders of the counties (these contents are excluded from the physical map). ${ }^{16}$ The symbolization (circular signatures) and classification of settlements according to the number of inhabitants are identical to those in the German editions. In the 1887 Croatian edition, the fortresses were designated by a special symbol and the capitals of provinces underlined (in later editions fortresses were excluded). Kocen's approach not to rely only on the size of a settlement, but also on its historical significance when choosing which place names should be labeled on the map, particularly advanced the educational process. The same approach was adopted in Croatian editions. Thanks to 
the selection of toponyms based on both population and their historical significance, the Croatian maps also included many smaller settlements important for Croatian history, such as Bužim, Cetin, or Stolni Biograd (in Hungary).

\subsection{Language redaction}

The most significant contribution of Croatian editors certainly relates to the linguistic redaction of geographical terminology. All map titles, explanation keys, texts on mathematical cartography, as well as the overall geographical nomenclature of maps (including diacritics) were translated into Croatian. Thus, the atlases had been adapted for the teaching in the Croatian language, as well as harmonized with valid geography textbooks. This was especially important for place names which in previous editions of school atlases were given in Germanized or Italianized forms. Slovenian, Montenegrin, Bosnian-Herzegovinian, and Serbian nomenclature was also given in their original forms.

Not only Croatian toponyms were given in Croatian language. Some of the geographical nomenclature of foreign countries is also translated into Croatian (exotoponyms). This refers equally to settlements (Wien - Beč, Graz - Gradac, Bratislava - Požun, Pécs - Pečuh, Venezia - Mletci, Eisenstadt - Željezni grad), oronyms (Bayerisches Alpenvorland - Bavarska visočina, Středo česká vrchovina - Srednja česka stupnjevina, Češko-moravska vrchovina - Češko-moravsko pogorje, Schweizer Jura - Švicarska jura, Erdélyi-érchegység - Erdeljsko rudogorje, Kisalföld - Mala ugarska nizina), as well as to the names of countries (Scotland - Škotska, Steiermark Štajerska, Schwaben - Švabska). Hydronyms are most often left with their original names except in the case of minor phonetic adaptations (e.g., Dija - Dyje, Adiža Adige). Exceptions were made with large rivers such as the Danube, the Rhine, the Po, and the Thames, which are written as Croatian exonyms (Dunav, Rajna, Pad, Temza). The names of foreign lakes are usually set in the original language and only appellations are translated (e.g., lake - jezero). The exception is Lake Balaton in Hungary, which is designated by its Croatian name (Mutno jezero). Aware of the unusualness of Croatian forms of certain foreign place names, the Croatian editors labeled some of those toponyms with double names - in Croatian and in its original language, e.g., Monakov (Munich), Rezno (Regensburg), Draždjan (Dresden), Pasov (Passau).

In later editions, the tendency of translating foreign nomenclature is less pronounced, so most of the foreign place names are given in their language of origin, including appellations (e.g. Boden See instead of Bodensko jezero). The longest-lived exotoponyms in Croatian atlas editions refer to names of neighboring countries with which Croatia had the strongest historical ties (Hungary, Austria, Italy). In 1934 and 1943 editions, most of the geographical nomenclature was written in the original languages. The only exceptions are the names of the seas and countries that had been retained in the Croatian version, and which, in accordance with international conventions, are still written as 
they are read in the language of the publisher (Jordan, 2005). Strange enough, Croatian editions of Kocen's atlas were not equipped with an index of foreign geographical names with their pronunciation (sprachliche Erläuterungen) that regularly appeared in German editions. The first such addition to Croatian editions appeared in 1934.

\section{CROATIAN EDITIONS OF KOCEN'S ATLAS AFTER 1887}

\subsection{Early Hranilović's editions}

The publication of the 1887 edition was followed by two editions, from 1889 and 1894 , which remained unchanged from the complete 1887 edition (Dörflinger and Hühnel, 1995, II, pp. 612-613). ${ }^{17}$ After Vincenz von Haardt, in collaboration with Wilhelm Schmidt, revised the German edition in 1897, supplementing it with new thematic maps of Austro-Hungary (maps of soil, relief, climate, forests, density of population, languages, urban network) these thematic maps were for the first time included in the Croatian edition that was published in $1900 .{ }^{18}$ From that edition onward, the editing of Kocen's atlas was taken over by Hinko Hranilović, ${ }^{19}$ who included 12 maps related to Austro-Hungary, two more than the German edition. ${ }^{20}$ Moreover, for the first time all the maps refer to the Greenwich prime meridian. In addition to the maps that can be found in the German edition, Hranilović kept two maps of Croatia and Slavonia (physical and political) according to Dobrilovićs earlier template, which he now supplemented with new contents (primarily in terms of administrative division and railway network). The maps of Croatia and Slavonia are now at a scale of 1:1,200,000, which is an enlargement in scale compared to 1887. Apart of the larger scale maps have been supplemented with many new toponyms. In addition, the physical map of Croatia and Slavonia was accompanied by an auxiliary map of Plitvice Lakes and longitudinal sections of the Croatian relief.

Furthermore, Hranilović improved the physical map of the karst countries $(1: 2,000,000)$ whose old Germanocentric title (Austrian karst countries) was now revised (Karst regions. Croatia, Slavonia, Dalmatia, Bosnia and Herzegovina, Istria, and Carniola). In addition, the first Croatian edition of the thematic maps of Austria-Hungary that appeared in this edition (which also refers to Croatian countries) made a significant advance in geography teaching. In addition to the abovementioned maps, Hranilović implemented several other innovations. In the introductory part of the atlas, he included the sheet titled Osnove kartografije [Basics of Cartography], which explains cartographic methods of presentation of different types of terrain. Although a similar sheet appears in the German edition, in the Croatian edition all examples of terrain are taken from Croatian maps so the sheet also contains five city maps of Zagreb of different scales. Hranilović also supplemented some maps taken from the German edition. E.g., he introduced isobaths on the maps of the northern 
and southern hemispheres and marked the depths of the sea with a color scale, which enabled an insight into the relief of the seabed. The good reception of Hranilovićs edition was confirmed in professional circles, so in 1903 a very positive review of the atlas was made in the Gazette of the Croatian Natural History Society, which praises the atlas and its innovations in teaching geography (Mandić, 1903, pp. 178-179).

\subsection{Second enlarged edition prepared by Hranilović and Modestin}

The Croatian edition of 1900 would be reissued more or less unchanged in 1903, 1906, and 1909. When Josip Modestin ${ }^{21}$ joined Hinko Hranilović in the editorial office of Kocen's atlas, together they prepared a new (second) enlarged Croatian edition in $1910^{22}$. Although the atlas had not been significantly revised in terms of content and number of maps (the content of the atlas is almost identical to the 1900 edition), this edition represents a qualitative leap in production. Instead of the previous 57 , the atlas now contains 78 maps on 51 sheets. There are 11 sheets on Austro-Hungary (one less than before). The biggest novelties in this edition are the geological map of AustriaHungary at a scale of 1:4,000,000, the improved toponymy of maps, and a much better representation of relief on physical map of Croatia and Slavonia (Figure 2). The political map of Croatia and Slavonia is now supplemented with auxiliary maps of Zagreb at four different scales and two aerial views of Zagreb taken from the Turul balloon in 1905 (Figure 3). This small but important acknowledgment to the city of Zagreb gave the atlas a stronger national note, emphasizing the Croatian capital. A physical map of the karst countries was also supplemented with an auxiliary map of Carniola and the Austrian Littoral at a scale of 1:1,250,000 which was of particular importance for the geography of Istria, which is here shown together with its Slovenian and Croatian hinterland (Figure 4). This 51-page edition would be reissued more or less unchanged several more times: in 1911, 1912, 1914, and 1918. 
The influence of Blaž Kocen and his geographical atlas on the development of Croatian school cartography

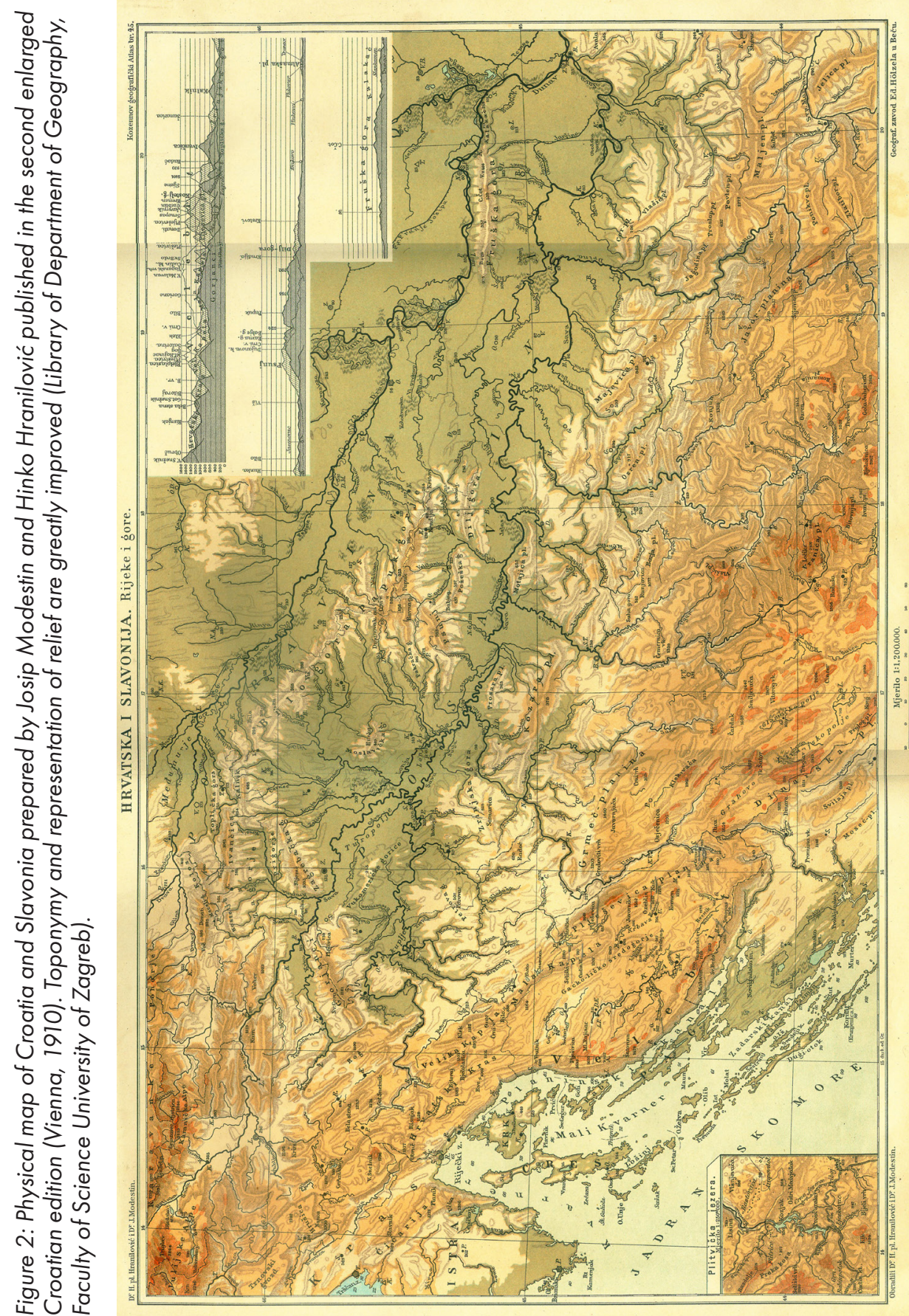


Figure 3: Auxiliary maps of Zagreb at four different scales and two aerial views of Zagreb taken from the Turul balloon in 1905 included in second enlarged Croatian edition of 1910 (Library of Department of Geography, Faculty of Science University of Zagreb).

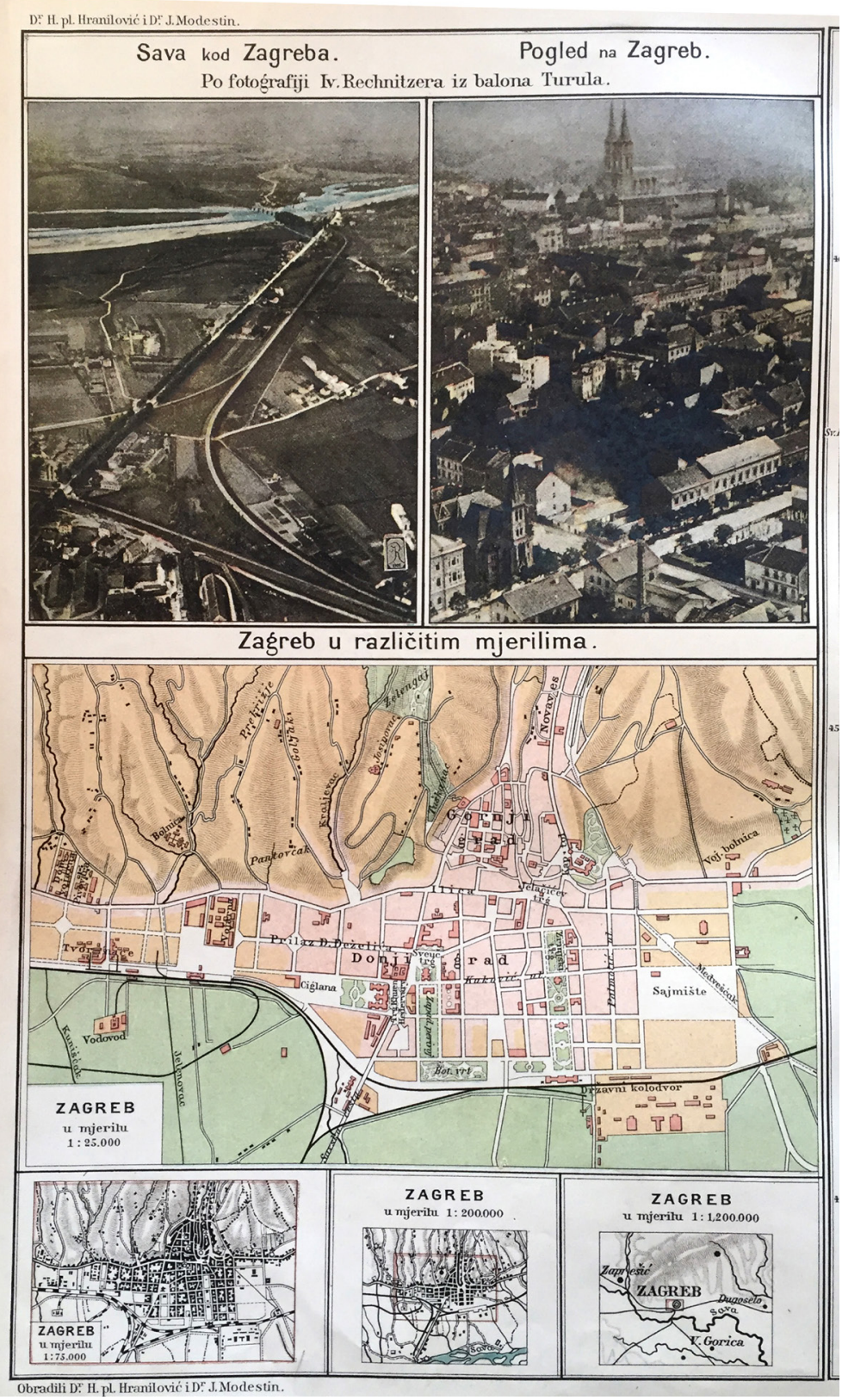


Figure 4: Auxiliary map of Carniola and Austrian Littoral showing Istria together with its Slovenian and Croatian hinterland. This is copy from 1914 edition (Croatian School Museum).

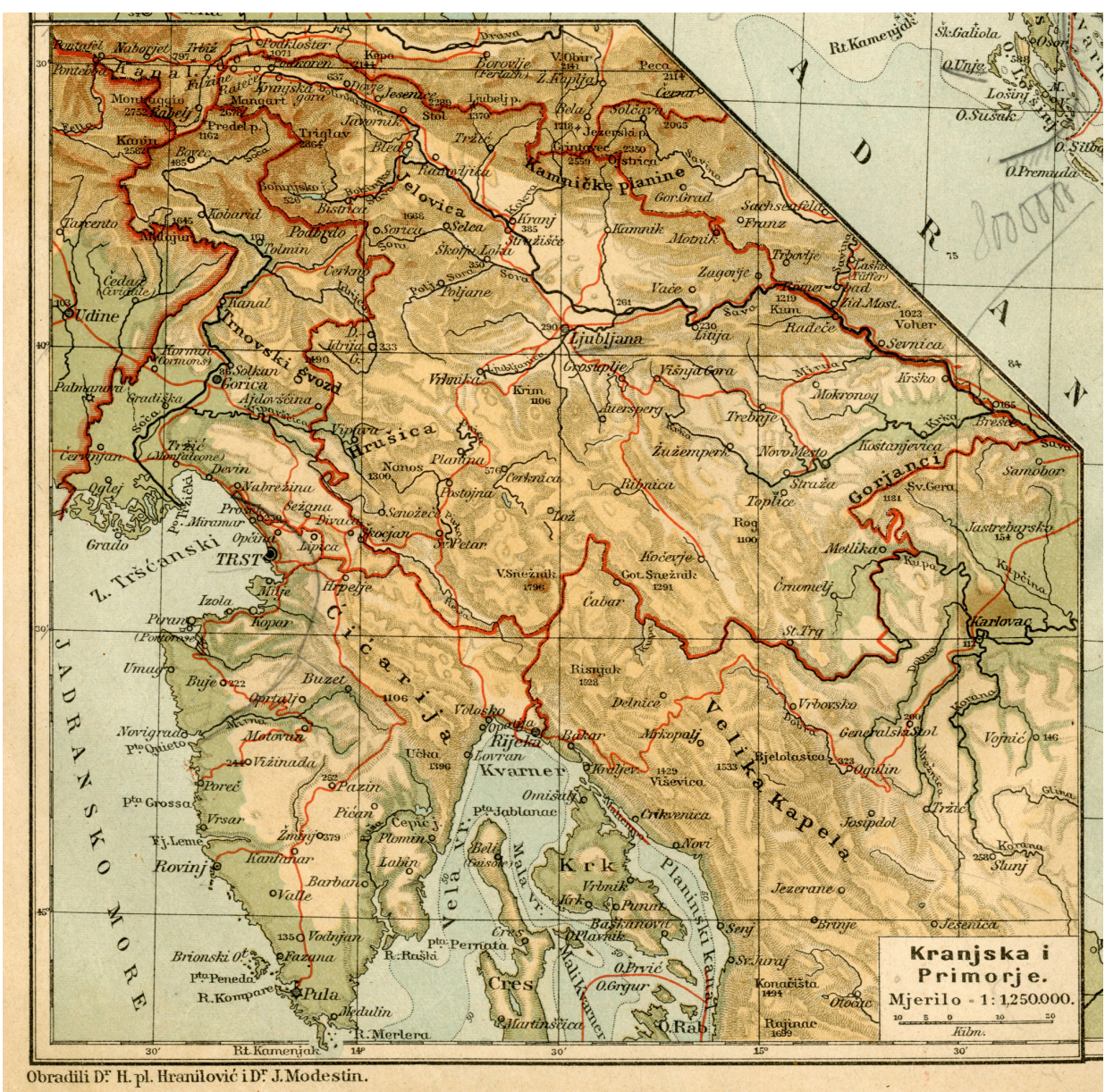

\subsection{Third enlarged edition prepared by Augustin Šenoa}

After 1918, the links between the German and other European editions of Kocen's atlas weakened. Although still united under the name of Blaž Kocen, national editions after 1918 became increasingly independent of German templates. This is primarily reflected in the changed geographical scope of the maps. The maps of the Austro-Hungarian area are now disappearing, and are replaced by maps of the newly formed nation-states or their parts. However, this would not happen immediately in 1918. Due to the war, even the German editions from 1918 and 1920 still do not reflect the geopolitical changes caused by the collapse of the Monarchy (Kretschmer, 1995, p. 219). Thus, the Croatian 
editions from 1918 and 1919 remain unchanged as well. The first supplemented German edition that brings significant changes regarding the former Austro-Hungarian space appears from 1921/1922. This edition also contains a new physical map of the Kingdom of Serbs, Croats and Slovenes at a scale of 1:2,500,000 (Kretschmer, 1995, p. 220). As early as 1922, under the leadership of Milan Šenoa, a new (third) revised edition of Kocen's atlas was prepared in Croatia, which would contain the same map of the Kingdom in the Croatian edition ${ }^{23}$. At that time, Milan Šenoa was one of the leading Croatian geographers and head of the Department of Geography at the Faculty of Philosophy, University of Zagreb. ${ }^{24}$ His most significant contribution to Croatian cartography is definitely his work on Croatian editions of Kocen's atlas published from 1922 to 1943. Hinko Hranilović and Josip Modestin still participated in the preparation of this edition. Although marked as the third revised edition, the only significant change was the inclusion of a physical map of the Kingdom of Serbs, Croats and Slovenes $(1: 2,500,000)$ adopted from German edition. In this edition, the physical map Croatia and Slavonia was retained, while the administrative map of the same area was omitted.

The atlas under the leadership of Milan Šenoa underwent significant changes only in 1934, when it changed its title to Kocenov geografski atlas. ${ }^{25}$ In this edition, Šenoa has new associates, the Croatian geography professor Ivo Juras ${ }^{26}$ and the Slovene geographer and cartographer Valter Bohinec. ${ }^{27}$ The inclusion of Bohinec in the editorial board of the Croatian edition was especially beneficial due to his dual role. Bohinec was an experienced and skilled cartographer, especially in making hypsometric maps, who helped Šenoa to compile new physical maps. In addition, the Croatian edition from 1934 (as well as the later one from 1939) was also prepared in the Slovene language for the needs of Slovene schools. Although in the Slovene version only the introductory pages were finally translated into Slovene while the maps and geographical terminology remained in the Croatian language, Bohinec's participation certainly contributed to the quality of both the Slovene and Croatian editions.

The Croatian 1934 edition is equipped with an index of foreign geographical names and their pronunciation, as well as with an explanation key. The world map and the celestial map are followed by a set of thematic maps of the world. Earlier chapters on mathematical geography with accompanying maps are omitted here. The volume of the atlas has now been reduced compared to some previous editions (48 pages), but the share of maps relating to Yugoslavia has increased significantly (as many as ten). Thus, immediately after the physical, the political, and the ethnographic map of Europe a whole set of maps on Yugoslavia are inserted. The physical map of the Kingdom of Serbs, Croats and Slovenes has now been renamed Yugoslavia, and supplemented with ancillary city maps of Belgrade, Zagreb, and Ljubljana. In addition to the physical map of the country, an administrative map with a division into counties (containing ancillary maps of the Sarajevo, Split, and Dubrovnik areas) is included as well. This is followed by two more detailed maps of Yugoslavia at a scale of 1:2,000,000: the southern counties (Banovinas) and the northwestern counties. Yugoslavia is also shown by a 
series of thematic maps at a scale of 1:5,000,000 which are also an original work of the editors: type of soil, distribution of forests and arable land, population density, traffic map, geological map by Kosta Petković, confessional map, and language map. Clearly outlined on the latter is Yugoslav unitarism, in which the only South Slavic language is Yugoslav. Due to the detailed hypsometric scale (undoubtedly the merit of Bohinec!), all physical maps in this edition are characterized by an extremely plastic and concise presentation of the relief. An interesting phenomenon is the appearance of small ancillary maps of Yugoslavia inserted into the political maps of North and South America and Australia, respectively. Although the didactic goal was to compare the size of the territories, linking the territories of Yugoslavia with the states in the Americas and Australia certainly had the goal of emphasizing the migrant ties between Yugoslavia and the abovementioned countries. This edition was reprinted twice more in 1938 and 1939 (in Croatian and Slovene) without significant changes.

A new edition of 1943, compiled after the establishment of the Independent State of Croatia (NDH) faithfully reflected all the changes in the educational and cultural policy of the new state. ${ }^{28}$ Symptomatically, Valter Bohinec and Ivo Juras disappeared from the editorial board. No less important, Milan Šenoa, who prepared the adapted edition for the needs of the Independent State of Croatia, was already retired at the time of preparing the atlas. Probably the relative security of his pension (he could not lose his position) allowed him to accept a job, and try to protect the geographical and didactic principles applied in this edition within the framework of his profession and his abilities. The introductory part of the atlas was now supplemented. In addition to the list of foreign geographical names with their pronunciation, for the first time, the atlas also contains a classic geographical index of all geographical names (domestic and foreign) with an indication of their position on the map. The 1943 edition underwent a significant linguistic revision. With the establishment of the Independent State of Croatia, the obligatory application of etymological spelling was introduced into the education system. As this required major interventions in the atlas, the new spelling was applied only in the index of geographical names while the geographical names according to the old spelling remained on the maps (this was the reason why the atlas received only a temporary use permit). Exceptions are maps of the Independent State of Croatia where the terminology is harmonized with the etymological spelling (e.g., Priedor instead of Prijedor). Šenoa wrote foreign geographical names in their original language, but there where they were forcibly replaced by German names he tried to avoid those names or possibly add them only in brackets, keeping the original place name in the first place such as Celje (Cilli), Warszawa (Warschau). In some places he completely avoided it. For example, in the annexed Sudetenland, he does not mention the German name Karlsbad for Karlovy Vary at all. For Ljubljana, he preferred to cite the etymological version of Lubiana in parentheses to avoid mentioning the German name Laibach. He did the same with Croatian town of Rijeka, which he mentions in the index as Rieka, avoiding to mention its official Italian name Fiume. 
Figure 5: Part of the map of Croatia with original Croatian and Slovene toponymies kept. Map was prepared by Milan Šenoa for edition of 1943 (Library of Department of Geography, Faculty of Science University of Zagreb.

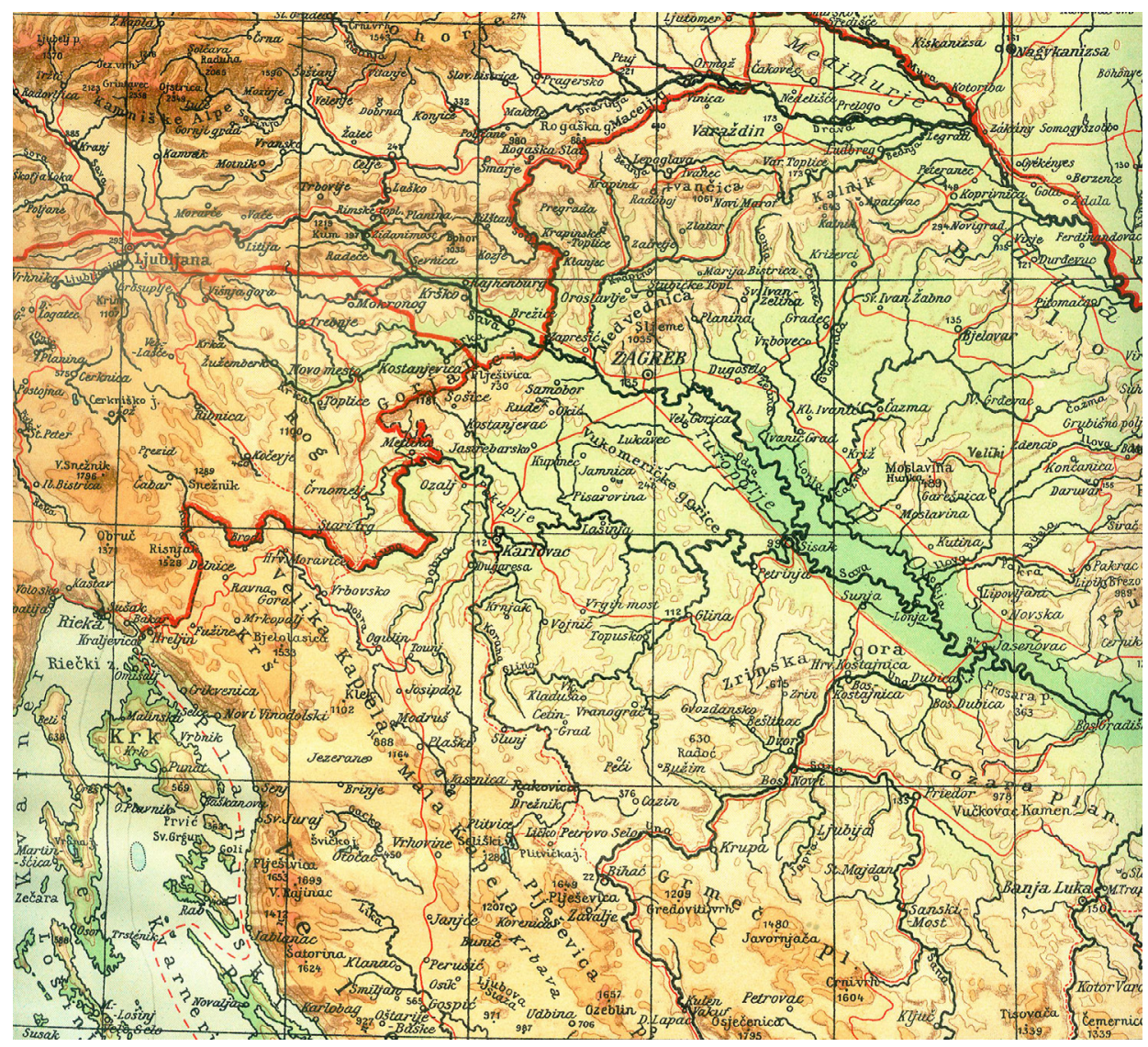

The sheet with the explanation key and the cartographic techniques used in the presentation of the terrain remained identical to those in the 1934 edition. In the introductory part, now included is one sheet of mathematical geography (taken from earlier Croatian editions). Although maps changed their order, being updated with new state borders, differences between the 1934 and 1943 editions were relatively small. As expected, the largest interventions were carried out on maps of Croatia. From the former map of Yugoslavia at a scale of 1:2,500,000, an overview map of the $\mathrm{NDH}$ at the same scale was now made, and by doubling it, what was obtained was a more detailed physical map of the $\mathrm{NDH}$ at a scale of 1:1,250,000 (Figure 5). The abovementioned maps of Croatia are now significantly improved. The relief is presented through a detailed and well-adapted hypsometric scale, which is supplemented 
with isohypses. This significantly improves the impression of three-dimensionality of the terrain, and increases the legibility of maps. The larger scale enabled a significant addition to the geographical nomenclature. In the Croatian territory annexed by Italy (Istria, Kvarner, part of Dalmatia) Šenoa retains Croatian place names (the only Italianized name he adopted in political map of Croatia was Fiume). In addition to numerous place names, the maps are supplemented with the names of numerous mountain peaks that are now appearing for the first time (in previous editions, the peaks were only indicated with height markings). In addition to the physical map, an administrative-territorial map of the Independent State of Croatia and four thematic maps of the same state were compiled. The language and confessional maps that appear in the 1934 edition are now omitted. The map of Central Europe is now renamed the Great German Reich (the new title is just pasted over the old one). The rest of the atlas relating to Europe and other continents, remained identical to the 1934 edition though with minor changes (borders).

\section{CONCLUDING REMARKS}

Kocen's geographical atlas played a key role in both the development of Croatian school cartography and the development of geography teaching. Its Croatian editions from 1887 were the first school geographical atlas in the Croatian language that was used as a didactic tool in teaching from 1887 onward until the end of the Second World War. About twenty Croatian editions published between 1887 and 1943 maintain the development of the geography curriculum, but also the political changes that the Croatian countries underwent at the end of the 19th and the beginning of the 20th centuries. Its appearance during the national movement and the struggle for the affirmation of the Croatian language in education and science gave it an important role in awakening national consciousness and building a common cultural identity of Croatian peoples. The creation of the first Croatian edition of Kocen's atlas was also encouraged by the founding of the Department of Geography at the Faculty of Philosophy, which began in 1883 under the leadership of Petar Matković. Its later editors were also the distinguished university professors of geography at the University of Zagreb, such as Hinko Hranilović and Milan Šenoa, who, in cooperation with high school teachers, adapted the atlas to the school curriculum and new didactic standards in teaching of geography. Its good adaptation to historical changes and national ideologies from Austrian centralism, Croatian nationalism to Yugoslav unitarism enabled its long-lasting use. ${ }^{29}$

The appearance of Dobrilovićs edition of Kocen's atlas was an announcement of a new era, and had far-reaching consequences for the development of Croatian school cartography and the manner of teaching geography. The introduction of school atlases and wall maps as teaching aids gained momentum in the 1880s. Around 1890 began a larger production of Croatian wall maps under the leadership of Ivan Steklasa who 
(according to Hungarian templates) prepared not only a large wall map of Croatia and Slavonia, but also school maps of each county for the use in teaching local geography. Last but not least, Steklasa edited Rothaug's geographical atlas, which was supposed to compete with Kocen's, but was not very successful ${ }^{30}$. Almost at the same time the first wall map of Dalmatia, which was prepared at the Hölzel Institute in Vienna and published in Zadar in 1892 appeared in the schools (Altić, 2019, pp. 122-123). ${ }^{31}$ Only a year after the appearance of the Croatian edition of Kocen's atlas, the first school atlas of Croatian history prepared by Vjekoslav Klaić ${ }^{32}$ was published, soon followed by the first wall maps of Croatian history. ${ }^{33}$

Changes in the Croatian editions of Kocen's atlas were most often associated with changes in German (sometimes Czech) editions. The early Croatian editions show a very high correlation with the simultaneous German editions, so the Croatian edition primarily referred to a language edition of the geographical nomenclature. Greater independence in editorial policy can only be noticed after 1918. The geographical scope of the maps, which sustains new political changes, is beginning to change significantly. In addition to increasing number of maps of national areas, their order changes, so that maps of nation-states move from the end of the atlas (where they represented the periphery of the Empire) to the beginning of the atlas, placing national territory at the center of interest. The diversification of maps by type is also obvious in the editions from the end of the 19th and the beginning of the 20th centuries. Apart from physical and political maps, there are more and more thematic maps. Types of thematic maps, on the other hand, maintain changes in geographical theory, which, in studying the geography of countries, no longer relies predominantly on the physical characteristics of the country (environmentalism typical of German scientific thought), but increasingly respects socio-geographical processes as a factor of geographical development (Black, 2000, p. 111).

The 1943 edition was the last edition of Kocen's atlas in the Croatian language. After the end of the Second World War, a new network of institutions was established in Croatia that were specialized in production of school atlases. In 1948, the publishing house Učila specializing in the production of didactic aids, including school atlases, wall maps, and globes was established. In 1983, this organization grew into Kartografija-Učila, from which emerged the public institution Croatian School Cartography, which still operates today.

\section{Notes}

1 Krajobraz Trojedne Kraljevine Dalmatinsko-Hérvatsko-Slavonske i pripadajućih delah Vojničke krajine kao što i pridnadležećih pokrajinah sa Turskom Hérvatskom, Hercegovinom, Cérnogorom i Bosnom narisan i preuzvišenomu, presvětlomu i prečastnomu gospodinu Josipu Jurju Strossmajeru Franjo Vjekoslav Kružić. 1:288,000. Zagreb: Dragutin Albrecht, 1861. Color lithograph in 9 sheets; $215 \times 148 \mathrm{~cm}$. 
The influence of Blaž Kocen and his geographical atlas on the development of Croatian school cartography

2 Zemljovid Hérvatske $i$ Slavonije $s$ Krajinom vojničkom sastavljen $i$ dubokim strahopoštovanjem posvetjen nj. preuzvišenosti gospodinu grofu Josipu Jellačiću Bužimskomu banu... = Karte von Croatien und Slavonien nebst der k.k. Militär Gränze entworfen und sr. exellenz herrn grafen Josef Jellačić von Bužim... / Michael Katzenschläger. 1:504,000. Vienna: Reiffenstein und Rosch, 1855. Color lithograph; $112 \times 65 \mathrm{~cm}$.

3 A special textbook was published in 1867 for the purpose of educating children in drawing maps. Ljudevit Modec, Rukovodnik u risanju zemljovida [A Guide in Drawing Maps] (Cuvaj, 1910, V, p. 469).

4 As a source he probably used the Ethnographische Karte der Oesterreichischen Monarchie by Karl von Czoernig from 1857.

5 The first thematic maps were included in the 1875 edition (a map of the Austro-Hungarian railway network and a map of the Central European railway). From 1887 a linguistic and ethnographic map of Austro-Hungary appeared as well.

6 Augustin Dobrilović (1843-ca 1907?) was a professor of history and geography and principal at the Gymnasium and associated Naval school in Kotor. Apart from being the author of the geography textbook, he stood out most as an editor of Croatian editions of historical and geographical school atlases.

7 Atlas antiquus: Historijsko-geografski školski atlas / izradili F. W. Schubert i W. Schmidt, za hrvacke škole udesio A. Dobrilović. Vienna: Eduard Hölzel, 1887. Atlas on 22 sheets.

8 Petar Matković (1830-1898) studied geography in Vienna, Prague and Berlin, where he attended the lectures of the historian Theodor Mommsen and geographer Eduard Ritter. Initially, he worked as a secondary school professor, and then taught geography at the University of Zagreb (1883-1893). Also, he was the founder of the Statistical Office for the Kingdoms of Croatia and Slavonia (1875), and member of the Yugoslav Academy of Arts and Sciences.

9 Kozennov školski atlas, hrvatski priredio A. Dobrilović, ravnatelj C.k. državne velike gimnazije u Kotoru. I dio Austro-Ugarska. Vienna: Eduard Hölzel, 1887. Atlas with 12 maps in color; $17 \times 25 \mathrm{~cm}$.

10 Kozennov geografijski atlas za srednje škole sa hrvatskim naukovnim jezikom / pripredio Augustin Dobrilović, ravnatelj c. $k$. državne gimnazije u Kotoru, uz reviziju dra. Petra Matkovića. Zagreb: Akademička knjižara Lavoslava Hartmana (Kugli \& Deutsch), 1887. Atlas with 37 maps.

11 The work of Vjekoslav Klaic, who in 1878 published his book about the geography of Bosnia and Herzegovina, describing them as predominantly Croatian countries, had a special influence on the development of this idea (Altić, 2019, p. 115).

12 Chorvatsko, Slavonie i Dalmacie. Blaž Kozennův zemépisný atlas pro školy střední. Vienna: Eduard Hölzel, 1876. Map Collection of the Faculty of Sciences, Charles University in Prague. Strangely enough, this map appeared only in the 1876 edition (Czech and German).

13 According to current knowledge, the map was published in 1855, and reissued in 1856, 1857, 1870, 1871, 1879, 1881, 1882, 1889, 1893, 1895, 1898, 1907, 1910, 1913, 1916, 1918, 1919, and 1920. From 1871 onwards, the map publication was continued by Vienna's publishing house Artaria \& Comp. 
14 Fizikalna karta Hrvatske, Slavonije i Dalmacije/ Karlo Herdliczka. 1:864,000. Vienna: F. Köke Lithographer, 1878. Color lithograph: $56 \times 56 \mathrm{~cm}$.

15 This is quite atypical given that the then official Austrian cartography still relied on Ferro. In fact, although Greenwich was introduced as the official meridian in 1884, the AustroHungarian Monarchy kept Ferro as the initial meridian on its official topographic maps until 1918.

16 In early Croatian editions of physical maps of Croatia and Slavonia, the positions of settlements are marked by the usual circular symbol and only the initial letter of the place name.

17 It should be noted that the dates of the Croatian editions for 1889 and 1894 are based on an estimate of two atlases with no original date. Not a single specimen from those years has been found in Croatia. Dörflinger and Hühnel dated these two undated Croatian editions according to the administrative-territorial structure and construction of the railway network.

18 Kozennov geografički atlas izrađen po V.v. Hardtu $i$ W. Schmidtu za srednje škole sa hrvatskim nastavnim jezikom priredio i upotpunio dr. Hinko pl. Hranilović, kr. Sveučilišni profesor, sadržaje 57 listova i 85 karata. Beč: Ed. Hölzel, Zagreb: glavno skladište za Hrvatsku, Slavoniju, Dalmaciju, Bosnu i Hercegovinu, knjižara L. Hartmana (Kugli \& Deutsch), 1900.

19 Hinko Hranilović (1860-1922) was a Croatian geographer. He studied geography, history, and philosophy at the Universities of Graz, Vienna, Berlin, and Oxford. In 1887, he was awarded a Doctorate in Physical Geography by the University of Graz. A secondary school teacher of geography at first, in 1892 he became an assistant to Professor Petar Matkovic at the Department of Geography of the Faculty of Philosophy, University of Zagreb. Full professor since 1908. One of the founders of the Geography Society in Zagreb (1897). He specialized in geographical theory, geographical methods, regional geography, and karst geography.

20 The German edition does not include two maps of Croatia and Slavonia.

21 Josip Modestin (1866-?) studied history and geography at the University of Zagreb. He worked as a high school teacher and principal of the Gymnasium in Rijeka. Author of two prominent geography textbooks in the Croatian language: Zemljopis i statistika AustroUgarske Monarhije za srednja učilišta [Geography and Statistics of the Austro-Hungarian Monarchy for Secondary Schools] (1903, 1905, 1916), Zemljopis za srednje škole po knjizi Dr Eduarda Richtera [Geography for Secondary Schools based on a book by Dr. Eduard Richter] $(1905,1908)$. He participated in the work on the Croatian edition of Kocen's atlas from 1910 to 1922.

${ }^{22}$ Kozennov geografički atlas za srednje škole (gimnazije, realke, trgovačke i učiteljske škole i slične zavode), obradili i upotpunili za škole sa hrvatskim nastavnim jezikom Dr. Hinko pl. Hranilović i Dr. Josip Modestin. 78 karata sa 199 sporednih karata na 51 listu po njemačkom izdanju koje obradiše dr. F. Heiderich i dr. F. Schmidt. Drugo prošireno $i$ prerađeno hrvatsko izdanje. Vienna: Ed. Hölzel, 1910.

23 Kozennov geografički atlas za srednje škole sa 78 karata sa 199 sporednih karata na 51 listu. Obradili i potpunili Hinko Hranilović, Josip Modestin i Milan Šenoa; po njemačkom izdanju F. Heidericha $i$ W. Schmidta 3. prošireno i prerađeno hrvatsko izdanje. Zagreb: St. Kugli, 1922. 
24 Milan Šenoa (1869-1961), Croatian geographer and writer. He graduated and received his PhD from the Faculty of Philosophy in Zagreb. At first he taught geography at the classical gymnasium in Zagreb and from 1910 started teaching at the Faculty. In 1918, he took over the position from Hranilovic as a head of the Department of Geography at the Faculty of Philosophy in Zagreb. From 1922 to 1940, when he retired, he was the head of the Geographical Institute, and from 1927 head of the Department of Regional and Social Geography (anthropogeography). He published about fifty papers on physical, regional and social geography, many travelogues, and popular geographical articles.

25 Kocenov geografski atlas. Priredio ga Dr. Milan Šenoa, prof. universiteta uz suradnju prof. Ive Jurasa i prof. dra V. Bohinca. Zagreb: St. Kugli, knjižara kralj. Sveučilišta i Jugoslavenske akademije, Zagreb, 1934. Atlas with 48 pages in color.

26 Ivo Juras (1866-1948), was born in Zadar. From 1905 to 1906 he studied geography and history in Zagreb, continuing his studies in Graz (1906-1907) and Vienna (1907-1909). He worked as a high school teacher in Zadar and Split. In 1942 he became the director of the Teachers' School in Zagreb, retiring in 1944. He was the author of numerous high school textbooks on geography, especially on Dalmatia. Apart from his work on Kocen's atlas, he is best known as the author of Pregled gospodarstva i trgovine u Dalmaciji [Review of the Economy and Trade in Dalmatia] (1910) and Zemljopis Jugoslavije, Kraljevine Srba, Hrvata i Slovenaca [Geography of Yugoslavia, the Kingdom of Serbs, Croats and Slovenes] (1922).

27 Valter Bohinec (1898-1984) was one of the first Slovene doctors of geography. He studied in Vienna, Naples, Zagreb, and Ljubljana. He received his doctorate in 1921 under the mentorship of Arthur Gavazzi. He worked at the Institute of Geography, as a high school teacher, and then for three decades as a map librarian at the National Library of Slovenia. He was one of the leading karstologists between the two world wars in Slovenia. He was also a prominent author of a number of school maps.

28 Kozenov zemljopisni atlas, priredio prof. dr. Milan Šenoa. Zagreb: St. Hugli, 1943. Atlas with 46 sheets, Lithographs in color.

29 This was not the case with the historical school atlas that Augustin Dobrilovic also prepared in 1887. It was the F. W. Putzgers Historischer Schul-Atlas that Dobrilovic translated into Croatian. However, its distinct Germanocentrism as well as the lack of historical maps relating to Croatian history did not leave it in use for long. The following year it was overshadowed by Klaić's Atlas za hrvatsku povijestnicu [Atlas of Croatian History].

30 Školski atlas na temelju metodike sastavljen po Ivanu Gj. Rothaugu, hrvatski priredio Ivan Steklasa, prof. kr. Učiteljske škole u Zagrebu. Zagreb: Lav. Hartman (Kugli i Deutsch), 1892.

31 Zemljovid Kraljevine Dalmacije = Carta del Regno di Dalmazia / Vinko plemeniti Haardt. 1:350 000. Wien, Zadar: Eduard Holzel, Komisiona naklada knjižare H. pl. Schönfelda, 1892. - Lithograph in color; $165 \times 125 \mathrm{~cm}$.

32 Atlas za hrvatsku povjestnicu/ sastavio ga Vjekoslav Klaić. U Zagrebu, litografija i štampa Carla Albrechta, 1888. Atlas with 6 maps: lithograph in color; $18 \times 24 \mathrm{~cm}$.

${ }^{33}$ Historički zemljovid Hrvatske (sa Slavonijom i Dalmacijom), Bosnom, Istrom i susjednim srpskim i slovenskim zemljama / zasnovao ga Vjekoslav Klaić, crtao Anton Jiroušek. 1:400 000. Zagreb, tipografija Margetić i drug, 1899. Lithograph in color; $168 \times 148 \mathrm{~cm}$. 


\section{References}

Altić, M., 2003. Povijesna kartografija: kartografski izvori u povijesnim znanostima [Historical Cartography: Cartographic Sources in Historical Sciences]. Zagreb: Publishing house Meridijani.

Altić, M., 2019. Cartography between imperial politics and national movements: $19^{\text {th }}$ century mapping of Croatia. Special issue of Cartographica 54/4, monograph 55, Toronto: University of Toronto Press.

Black, J., 2000. Maps and history, constructing images of the past. New Haven and London: Yale University Press.

Bradaška, F., 1867. Sravnjivajući zemljopis za više razrede srĕdnjih učionah [Geography for the Higher Grades of Secondary Schools], Zagreb: Ljudevit Gaj.

Bratec Mrvar, R., Lukas B., Fridl, J., Kladnik, D., Kunaver J., 2011. Kocenov srednješolski atlas kot didaktična prelomnica. Ljubljana: Založba ZRC.

Cuvaj, A., 1910. Građa za povijest školstva: sv. IV od 31. prosinca 1851. do 20. listopada 1860. [Sources for the History of Education: Volume IV for Period December 31, 1851 - 20 October, 1860]. Zagreb: Kr. hrv.-slav.-dalm. zem. vlada, Odjelaza bogošt. i nastavu.

Cuvaj, A., 1910. Građa za povijest školstva: sv. V od 20. listopada 1860. do 20. travnja 1868. [Sources for the History of Education: Volume V for Period October 20, 1860 20 April 20, 1868]. Zagreb: Kr. hrv.-slav.-dalm. zem. vlada, Odjela za bogošt. i nastavu.

Dobrilović, A., 1887. Zemljopis za niže razrede srednjih škola [Geography for Lower Grades of Secondary School]. Zadar: Brzotiskom Narodnog lista.

Dörflinger, J., Hühnel, H., 1995. Atlantes Austriaci, Österreichische Atlanten 1. Band 1561-1918, 2 Teilband. Wien: Böhlau Verlag.

Gross, M., Szabo, A., 1992. Prema hrvatskome građanskom društvu. [Towards the Croatian Bourgeois Society]. Zagreb: Nakladni zavod Globus.

Jelavich, C., 1992. Južnoslavenski nacionalizmi, jugoslavensko ujedinjenje i udžbenici prije 1914 [South Slav Nationalisms, Texbooks and Yugoslav Union before 1914]. Zagreb: Nakladni zavod Globus i Školska knjiga.

Klaić, V., 1888. Atlas za hrvatsku povjestnicu, sastavio ga Vjekoslav Klaić. Zagreb: Carl Albrecht.

Kretschmer, I., 1995. Atlantes Austriaci, Österreichische Atlanten 2. Band 1919-1994. Wien: Böhlau Verlag.

Mandić, D., 1903. Kozennov geografički atlas izrađen po V. v. Hardtz i W.Schmidrtu. Za srednje škole s hrvatski nastavnim jezikom priredio i upotpunio dr. Hinko pl. Hranilović. Glasnik hrvatskoga naravoslovnog društva, XIV, pp. 178-179.

Mařik, V., 1861. Kratak opis Carevine Austrijanske [A Brief Description on the Austrian Empire]. Zagreb: Dragutin Albrecht.

Mařik, V., 1865. Zemljopis Trojedne Kraljevine [Geography of the Triune Kingdom]. Zagreb: Dragutin Albrecht. 
Matković, P., 1866. Statistika Austrijske Carevine [The Statistics of the Austrian Empire]. Zagreb: Narodna tiskarnica Ljudevita Gaja.

Matković, P., 1874. Geografsko-statistički pregled Austro-Ugarske Monarhije [Geographical and Statistical Review of the Austro-Hungarian Monarchy]. Zagreb: Narodna tiskara dra. Ljudevita Gaja.

Modec, Lj., 1867. Rukovodnik u risanju zemljovida [A Guide in Drawing Maps]. Zagreb: [s.n.].

Modrić Blivajs, D., 2007. Kakvi su bili povijesni srednjoškolski udžbenici u banskoj Hrvatskoj u razdoblju Khuenova banovanja? [What's like the history textbooks in Croatia during the Era of Ban Khuen were?]. Časopis za suvremenu povijest, 3, pp. 777-849.

Sabljar, V., 1866. Miestopisni rječnik kraljevinah Dalmacije, Hervatske i Slavonije [The Toponymic Dictionary of the Kingdoms of Dalmatia, Croatia and Slavonia]. Zagreb: Antun Jakić.

Stančić, N., 2002. Hrvatska nacija i nacionalizam u 19. i 20. stoljeću [Croatian Nation and Nationalism in the $19^{\text {th }}$ and $20^{\text {th }}$ Centuries]. Zagreb: Barbat.

Zoričić, P., 1865. Zemljopis za niže gimnazije i realke. Zagreb: Narodna tiskarna dra. Ljudevita Gaja.

\section{VPLIV BLAŽA KOCENA (BLASIUSA KOZENNA) IN NJEGOVEGA GEOGRAFSKEGA ATLASA NA RAZVOJ HRVAŠKE ŠOLSKE KARTOGRAFIJE}

\section{Povzetek}

Blaž Kocen, poznan tudi kot Blasius Kozenn (1821, Hotunje pri Ponikvi-1871, Dunaj), je eden najbolj znanih slovenskih geografov in kartografov. Deloval je v razburkanih časih, ki jih je zaznamovala tudi modernizacija izobraževalnega sistema v deželah Avstrijskega cesarstva oz. Avstro-Ogrske (od 1. 1867). Sprva je študiral za duhovnika, potem pa se je izobrazil na področju matematike, fizike in naravoslovja; odlikoval se je pri pouku geografije, pri čemer je zagovarjal uporabo bolj naprednih učnih orodij, Da bi izboljšal proces poučevanja je Kocen napisal nekaj geografskih učbenikov in zbral različne stenske in namizne karte. Nedvomno je Kocenov glavni dosežek njegov šolski geografski atlas. Ko je 1.1861 izšla prva izdaja njegovega atlasa (Kocen's Geographischer Schul-Atlas für die Gymnasien, Real- und Handels-Schulen) kot prvega šolskega geografskega atlasa za uporabo v deželah Avstrijskega cesarstva, je bil znanstvena in didaktična senzacija. Prvič so učitelji geografije dobili priročnik v obliki atlasa, ki je bil usklajen z učnim načrtom dežel cesarstva. Po prvi izdaji je bil atlas deležen številnih izboljšav in prilagoditev novim zgodovinskim okoliščinam, 
tudi po avtorjevi prezgodnji smrti, in je tako pustil trajen pečat na šolski geografiji v vseh srednjeevropskih državah. Na temelju Kocenove predloge so kmalu sledile prilagojene izdaje $v$ hrvaščini, češčini, madžarščini in poljščini. Tako je ta atlas postaj najpomembnejši geografski šolski atlas v Avstro-Ogrski.

V 19. stoletju sta bili geografija in kartografija prepoznani kot pomembno orodje hrvaške kulturne nacionalne identitete, še posebej v izobraževalni razsežnosti. V skladu s tem je sedemdeseta in osemdeseta leta 19. stoletja zaznamoval pojav prvih geografskih učbenikov in priročnikov $\mathrm{v}$ hrvaškem jeziku. $\mathrm{V}$ okviru prilagajanja šolskih programov novim okoliščinam se je začela razvijati hrvaška šolska kartografija, pri čemer je ime Blaža Kocena igralo še posebej pomembno vlogo. Kocenov šolski atlas, ki ga je leta 1887 prevedel in prilagodil hrvaškemu šolskemu programu Augustin Dobrilović, je bil prvi zemljepisni atlas v hrvaškem jeziku. V obdobju med letoma 1887 in 1943 je izšlo okoli dvajset hrvaških izdaj, njihovi uredniki pa so bili najvidnejši profesorji geografije, kot npr. Petar Matković, Hinko Hranilović, Josip Modestin, Milan Šenoa, pri pripravljanju izdaj v letih 1934, 1838 in 1939 pa je sodeloval tudi slovenski geograf Valter Bohinec. Kocenovi atlasi so imeli ključno vlogo pri pouku geografije in so bili poleg učbenikov najpomembnejše sredstvo geografskega izobraževanja na Hrvaškem.

V prispevku smo analizirali pomen Kocenovih atlasov za razvoj hrvaške šolske kartografije. S primerjavo nemških in hrvaških izdaj med letoma 1887 in 1943 smo predstavili razvoj na področju tiskanja zemljevidov, kartografskih tehnik, jezikovnih redakcij toponimike in vključevanja tematskih kart ter vpliv političnega diskurza (nemški centralizem proti slovanskim nacionalizmom) na geografski obseg in vsebino zemljevidov, ki so jih uporabljali v izobraževalnem procesu. 